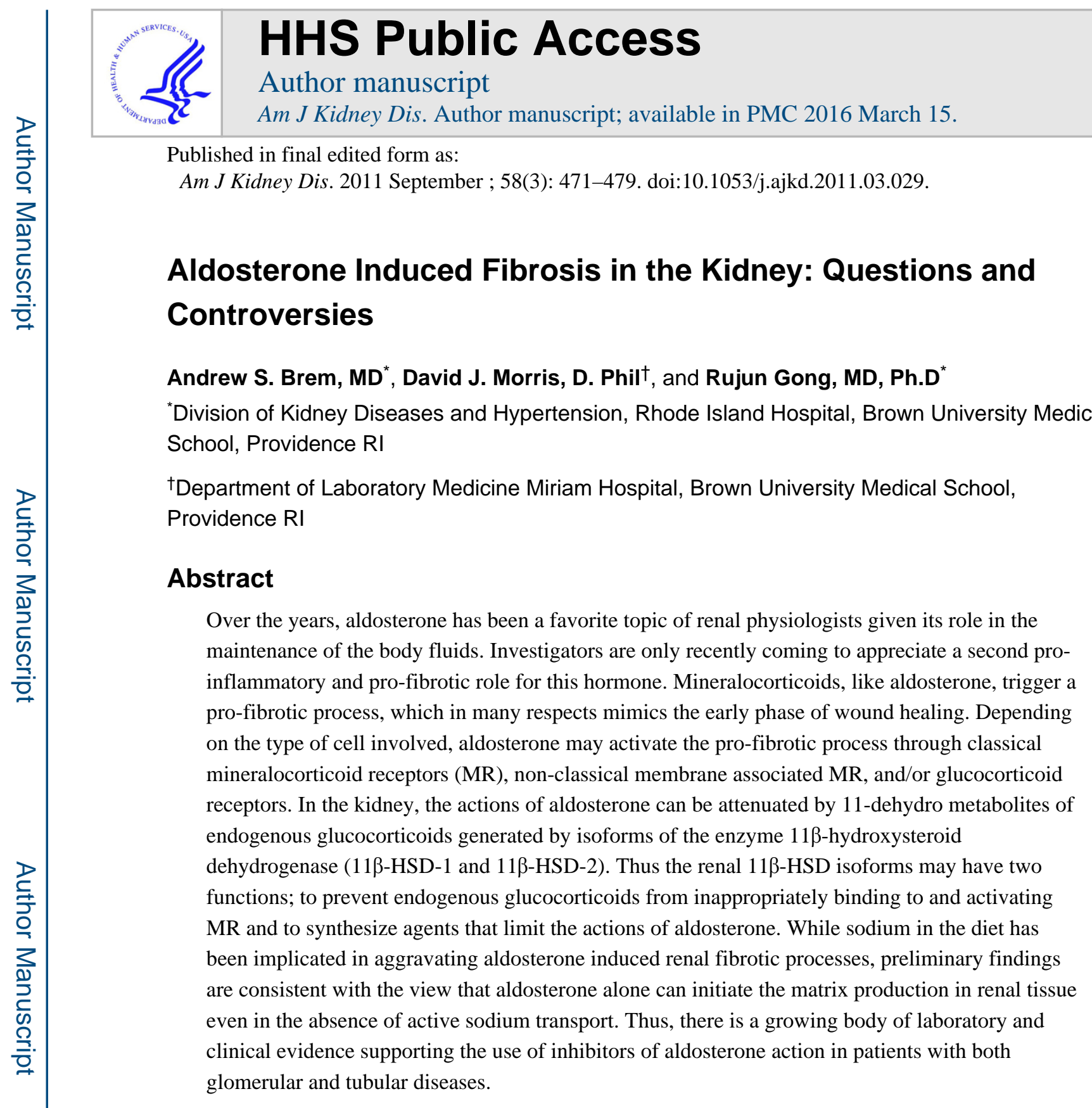

\title{
BACKGROUND
}

Since its isolation and characterization in the early 1950's, aldosterone has captivated renal physiologists. From their early efforts, we now appreciate how picomolar concentrations of aldosterone produced in the adrenal cortex glomerulosa cells regulate our electrolyte balance, our extracellular fluid volume, and our very survival. Hostetter and his colleagues were among the first to suggest that this life-preserving hormone might also have a darker side by demonstrating that aldosterone can contribute to renal injury ${ }^{1}$. The idea that aldosterone has an additional function as a pro-inflammatory and/or pro-fibrotic agent was actually proposed years earlier by Hans Selye shortly after aldosterone itself was discovered ${ }^{2}$. His hypothesis and observations were largely set aside until relatively recently.

Address correspondence to: Rujun Gong, MD, PhD, Division of Nephrology, Rhode Island Hospital, Brown University Medical School, 593 Eddy Street, Providence, R.I. 02903, Tel: (401) 444-0989, Fax: (401) 444-6849, Rujun_Gong@ Brown.edu. 
The fundamental question is why would a hormone so essential for our survival be also linked to inflammation and scarring? The question is obviously rhetorical; one can only surmise that during our earliest times, the two overwhelming and immediate external threats to existence were loss of circulating volume and an insufficient response to a wound injury. Could one hormone address both threats?

The idea that aldosterone is pro-inflammatory and pro-fibrotic even raises the possibility of the mineralocorticoid playing a role in wound healing. Recently, investigators have suggested that aldosterone is actively involved in the inflammatory and fibrotic responses associated with normal surgical wound healing ${ }^{3,4}$. Aldosterone has been shown to activate a key kinase pathway called mTOR (mammalian Target of Rapamycin), which promotes cell proliferation $^{5}$ and this same pathway is turned on during the early phases of wound healing 6 and of renal repair after injury ${ }^{7}$. Excessive or prolonged activation of mTOR appears to promote interstitial inflammation and fibrosis ${ }^{7}$. It turns out that mTOR also plays a role in activating the sodium channel in renal collecting duct cells by phosphorylating SGK1 (serum and glucocorticoid induced kinase 1$)^{8}$; SGK1 is a key enzyme triggered by aldosterone during sodium transport ${ }^{9}$. As a corollary, inhibitors of the mTOR pathway like rapamycin are known to significantly delay or blunt wound healing 6 .

\section{CASE VIGNETTE}

A 5 year old African American girl was noted to have a blood pressure of 140/90 during a routine yearly visit to her pediatrician. She had been receiving no medications but she had been eating a moderately high salt diet. Her only complaint was that she had occasional headaches and felt tired at times. There was no edema or acute weight change noted. The immediate family history was negative for renal disease and hypertension. Her height and weight were in the $60^{\text {th }}$ and $50^{\text {th }}$ percentile respectively and the blood pressure of $140 / 90$ sitting at rest was confirmed. Her initial laboratory evaluation revealed a serum potassium of $2.7 \mathrm{mEq} / \mathrm{L}$ and a serum bicarbonate of $33 \mathrm{mmol} / \mathrm{L}$. Her plasma renin on a moderately high salt diet was $0.1 \mathrm{ng} / \mathrm{ml} /$ hour $(0.028 \mathrm{ng} / \mathrm{L} / \mathrm{sec})$ (normal $1.1 \pm 0.8 \mathrm{ng} / \mathrm{ml} /$ hour or $0.31 \pm 0.22$ $\mathrm{ng} / \mathrm{L} / \mathrm{sec}$ ) and serum aldosterone was $49 \mathrm{ng} / \mathrm{dl}(1359 \mathrm{pmol} / \mathrm{L}$ ) (normal 2 to $9 \mathrm{ng} / \mathrm{dl}$ or 55.5 to $249 \mathrm{pmol} / \mathrm{L})$. Her renal function was normal with a serum creatinine of $0.5 \mathrm{mg} / \mathrm{dl}(44.5$ $\mu \mathrm{mol} / \mathrm{L}$ ) (Schwartz pediatric formula ${ }^{10}$ e-GFR $130 \mathrm{ml} / \mathrm{min} / 1.73 \mathrm{~m}^{2}$ )and a random urine analysis demonstrated a specific gravity of 1.013 with a $\mathrm{pH}$ of 7 , trace protein and no cells or casts. Other studies included a normal 24 hour urinary cortisol and an elevated 18 hydroxycorticosterone. A CT scan initially and again at six months showed no discrete changes in either adrenal gland.

The patient was treated with spironolactone resulting in a modest reduction in blood pressure to 132/84. Approximately 6 months after her presentation, she underwent a scan using ${ }^{131}$ I labeled methylcholesterol $\left({ }^{131} \mathrm{I}-\mathrm{NP}-59\right)$ with dexamethasone and potassium iodide pretreatment. The scan localized the activity to the left adrenal gland and the patient electively then underwent surgical removal of that gland. The pathology revealed diffuse nodular changes consistent with adrenal hyperplasia. Although her blood pressure and serum potassium initially normalized after her surgery, her hypertension and electrolyte abnormalities re-occurred 2 years later. She was restarted on spironolactone and other 
antihypertensive agents but compliance with medications and dietary sodium restriction was limited. By early adolescence, her serum creatinine had risen to $1.0 \mathrm{mg} / \mathrm{dl}(89.0 \mu \mathrm{mol} / \mathrm{L})$ (Schwartz pediatric formula ${ }^{10} \mathrm{e}-\mathrm{GFR} 92 \mathrm{ml} / \mathrm{min} / 1.73 \mathrm{~m}^{2}$ ) and she developed low grade but persistent proteinuria. (This case vignette was based on case previously reported by Brem et $\mathrm{al}^{11}$ )

\section{PATHOGENESIS}

Over the last 10 or 15 years, aldosterone's roles in inflammation and injury have been rigorously examined in two major disease model systems, cardiovascular and renal disease. Rocha $^{12}$, Weber ${ }^{13}$, Young ${ }^{14}$, Brown $^{15}$, Funder ${ }^{16}$ and numerous others have each elegantly expanded the current understanding of aldosterone's role in the pathogenesis of cardiovascular disease. Recent reviews have specifically summarized the role aldosterone plays in renal injury yet many questions remain to be answered ${ }^{17-19}$. Rather than dwell on what has already been said, we plan to focus this review on questions largely unaddressed in previous publications: is aldosterone capable of actually promoting disease on its own or is it an adjunct player modifying pre-existing renal disease, which receptor pathways might be involved, and what mechanisms normally might keep the fibrotic pathways in check. A very brief general description of what is known about aldosterone and its role in the response to renal injury seems appropriate before we address these questions.

\section{Renal Responses to Injury}

Recent reviews ${ }^{20-23}$ have characterized the various steps in the renal responses to injury and we will only briefly present the relevant highlights from those reviews. Following renal injury, pro-inflammatory chemokines like MCP-1 (monocyte chemoattractant protein-1) and RANTES are released from damaged cells ${ }^{24}$. The increase in COX-2 expression, considered to be a pro-inflammatory marker, leads to the local generation of vaso-dilating prostaglandins and a net increase in blood flow to the injured area. These prostaglandins counter ischemia-inducing peptides like endothelin-I and angiotensin II, which are released from damaged vascular beds. Mononuclear cells are also recruited to the damaged area by various chemoattractant and leukocyte adhesion molecules. A series of chemical reactions lead to the local production of reactive oxygen species (ROS), which ultimately result in the disruption of foreign proteins ${ }^{5}$. ROS are bactericidal and are also part of the initial inflammatory process. As the development of initial injury matures, the process of fibrogenesis follows a similar pattern to normal wound healing. Activated fibroblasts (myofibroblasts) either migrate to the injured area or are formed in situ from residual renal tubular epithelial cells in a process known as epithelial to mesenchymal transition (EMT). Activated pro-fibrotic growth factors including insulin-like-growth factor-1, connective tissue growth factor, angiotensin II, and transforming growth factor-beta are elaborated from the damaged tissue to promote the production of more myofibroblasts and the net generation of extracellular matrix.

In the next phase, damaged tissues can either heal with a return to normal structure and function or be converted into non-functional fibrotic scar. The course of events largely is determined by the extent of the injury and by whether factors favor excessive matrix synthesis with excessive maladaptive EMT or factors limit matrix accumulation by 
promoting matrix degradation accompanied by the regeneration of normal cells. Fibrosis may then result from over amplification of the fibrogenic factors following a single severe injury or repeated bouts of injury occurring over time. Normally matrix provides the structural support for replacement cells and consists of proteins including collagens I and III so its generation is a necessary element of both healing and repair. However in damaged kidneys, the matrix also contains novel chains of collagen IV and fibronectin. This type of excess matrix forms cross linkages, which makes it difficult to break down and leads to scar rather than normal replacement tissue.

\section{RECENT ADVANCES}

\section{The Role of Aldosterone in Renal Fibrosis}

Human and whole animal studies have clearly implicated aldosterone as player in renal injury, inflammation, and ensuing fibrosis ${ }^{25,26}$. However, most of these studies describe a beneficial effect of aldosterone antagonists in pre-existing forms of renal injury ${ }^{1,27-29}$. What is the evidence that aldosterone itself can contribute to injury, inflammation, and the fibrotic response (see figure 1)? Aldosterone and deoxycorticosterone (DOCA), a cousin mineralocorticoid, can both activate circulating lymphocytes ${ }^{30}$ and locally increase superoxide production (ROS) through activation of NADPH oxidase in mesangial cells ${ }^{5,31}$. Activation of $\mathrm{T}$ cells and superoxide production are part of the first phase of inflammation. In mesangial cells ${ }^{32}$ and in collecting duct epithelial cells ${ }^{33}$, aldosterone promotes the phosphorylation of serum glucocorticoid kinase-1 (SGK-1), which then leads to phosphorylaton of IKB and its subsequent inactivation and activation of NF-KB. The NF$\mathrm{KB}$ translocates to the nucleus and stimulates additional genes responsible for the inflammatory and fibrotic processes including CTGF and TGF- $\beta$. Mineralocorticoids also have been implicated in promoting EMT and apoptosis in proximal renal tubules ${ }^{34}$ as well as renal interstitial fibrosis ${ }^{35}$. Interestingly, many of the studies mentioned above used supra-physiological concentrations of mineralocorticoid coupled with induced injury to achieve these effects. Recently, our laboratory demonstrated that low concentrations of aldosterone $(10 \mathrm{nM})$ can directly induce early fibrotic changes in cultured renal collecting duct cells (CCD) in as little as 48 hours $^{36}$. This response in CCD cells, which contain MR and $11 \beta-H S D-2$ is consistent with activation of genomic processes. Moreover, the observed significant increase in extracellular matrix (collagen) occurred in the absence of inflammatory cells. In contrast, we did not observe any changes in cultured proximal tubule epithelial cells, which lack a mineralocorticoid receptor.

From the discussion above, it is clear aldosterone can contribute to renal injury and inflammation but can the hormone itself actually induce fibrotic changes in the kidney in vivo? There are several lines of evidence that under certain conditions, aldosterone alone can. Reungui and co-workers ${ }^{37}$ demonstrated that over a 20 study week period, treatment with thiazide diuretics was associated with an increase in osteopontin expression and an increase in oxidative stress in rats. These changes did not correlate with hypokalemia but were related to hyperaldosteronism ${ }^{37}$. Leroy and her associates ${ }^{33}$ showed that in rats fed a very sodium restricted diet, the NF- $\kappa$ B pathway and PAI-1 mRNA were activated in renal cortical collecting ducts after only one week. The effects were produced by endogenous 
aldosterone. These effects could be blocked if the animals were treated with spironolactone. Our laboratory explored this question in a murine model ${ }^{36}$. Mice were either adrenalectomized or left adrenally intact and treated with aldosterone $8 \mu \mathrm{grams} / \mathrm{kg} / \mathrm{day}$ delivered via an Alzet pump for one week. This intervention gives levels of aldosterone that are high physiologic approximating what one might see with chronic administration of diuretics. Early fibrotic changes characterized by increased interstitial collagen accumulation and mesangial hypercellularity were observed in aldosterone treated adrenally intact mice but were much more noticeable in the aldosterone treated adrenalectomized mice (figure 2). These changes directly correlated with elevated expression of collagen,

fibronectin, and connective tissue growth factor relative to controls. If the aldsterone treated mice were also given the aldosterone inhibitor RU-318 or the 11/-HSD end product 11dehydrocorticosterone, the aldosterone induced fibrotic changes were attenuated. The mice in the study were not hypertensive and did not have pre-existing renal disease or injury. Thus it appears as though aldosterone alone can, under selected circumstances, induce fibrotic changes in the kidney in vivo.

Despite the growing number of publications in this area, certain issues remain unresolved. Most notably, cells like lymphocytes ${ }^{30}$, vascular muscle cells ${ }^{30}$, and mesangial cells ${ }^{5}$ appear to express putative mineralocorticoid receptors (MRs) but those receptors do not appear to function as classical MRs (figure 3). Classical MRs, as exist in renal collecting duct epithelial cells, bind aldosterone in the cytosol, then the MR-hormone complex translocates to the nucleus, and induces genes that produce specific proteins; a process requiring at least 90 minutes or so before biologic events begin to occur ${ }^{38-41}$. Atypical or non-classical MRs, which appear to exist in white blood cells ${ }^{30}$, vascular tissue ${ }^{30,42}$, mesangial cells ${ }^{5}$, and podocytes ${ }^{43}$, are located in the cell membrane and bind aldosterone with a binding affinity for aldosterone that appears to be an order of magnitude higher than cytosolic classical $\mathrm{MRs}^{30}$. Once bound to this atypical membrane-associated receptor, aldosterone almost immediately induces effects that are non genomic. These non-classical MRs are involved in cell signaling and when activated, generate a spike in cytosolic calcium occurring in seconds accompanied by a fall in intracellular $\mathrm{pH}$ followed by a rise in sodium-hydrogen ion exchange activity with an increase in intracellular sodium and $\mathrm{pH}^{30,42}$. In mesangial cells, inhibition of protein synthesis does not appear to affect the changes induced by aldosterone, consistent with the idea that non-classical MR activation does not lead to gene induction and generation of new proteins ${ }^{5}$. The question then is how do aldosterone activated processes, presumably mediated through non-classical MR and with signals lasting seconds to minutes, lead to chronic irreversible fibrotic changes?

In mesangial ${ }^{32}$ and perhaps other renal cells like podocytes ${ }^{43}$, non-classical MR activation is associated with up-regulation of serum and glucocorticoid kinase 1 (SGK-1), an enzyme that aldosterone also stimulates when classical MRs are activated for sodium transport in renal collecting duct epithelial cells ${ }^{9,44}$. Gene pathways, which are likely pro-fibrotic including upregulation of the NF- $\mathrm{KB}$ pathway and the expression of connective tissue growth factor, fibronectin, and collagen 1, are also activated in sodium transporting renal collecting duct epithelial cells after more prolonged aldosterone exposure ${ }^{33,36,45}$. In most of the above studies involving cells with non-classical MRs, the maximum biologic response required 
concentrations of aldosterone of $100 \mathrm{nM}$ or more and commenced within an hour of exposure to the hormone. When activated, these non-classical MRs clearly are associated with fibrotic changes in the kidney and may contribute indirectly to genomic processes ${ }^{32,46}$. However, the potential for fibrosis to occur probably depends on the continued presence of non-classical MRs in the cell membrane and exposure to high concentrations of aldosterone over time to maintain the signal. Most cells normally recycle membrane bound receptors and limit the exposure of those receptors in the cell membrane when the ligand levels are excessive. If non-classical MRs behave as one might expect, aldosterone induced profibrotic signaling should normally be limited and may only occur under conditions where the hormone levels are excessively high.

Whether and/or how aldosterone may influence fibrotic changes in renal proximal tubules is a question that has a complicated answer. Aldosterone has been reported to induce apoptosis and possibly to promote epithelial to mesenchymal transition in proximal tubule epithelial cells $^{34}$. However in our laboratory, high but physiologically attainable concentrations of aldosterone $(10 \mathrm{nM})$ appear to have no effect on either cell transformation or extracellular matrix production after 48 hours $^{36}$. It is generally well accepted that classical MRs do not exist in this segment and the existence of non-classical MRs is controversial. Since aldosterone can bind to glucocorticoid receptors (GRs) when concentrations exceed 100 $\mathrm{nM}^{47}$, some mineralocorticoid effects may be mediated through the hormone binding to glucocorticoid receptors present in cells ${ }^{46}$ (figure 3 ). Activation of GRs leads to upregulation of connective tissue growth factor (CTGF), a known early pro-fibrotic protein ${ }^{48}$. CTGF and other pro-fibrotic pathways can be partially blocked by the GR antagonist RU-486 so it does appear that some of the aldosterone induced pro-fibrotic events could be mediated by GRs.

Renal collecting duct epithelial cells containing classical MRs normally respond to aldosterone by increasing sodium transport and potassium secretion, an effect that only lasts a period of hours after exposure to the hormone ${ }^{38}$. Pro-fibrotic changes recently described in cultured renal collecting duct cells require a more prolonged period of aldosterone exposure (48 hours) before they occur ${ }^{36}$ but these changes can be induced with concentrations of aldosterone that induce sodium transport and are in the high physiologic range. What then prevents aldosterone from inducing fibrosis all the time? As we also have reviewed elsewhere ${ }^{49}$, some years ago, various investigators observed a paradox involving aldosterone and its effects on electrolyte transport: the impact of aldosterone on sodium transport was evident in preparations of cell membrane from toad bladder ${ }^{50}$ and isolated perfused renal collecting ducts ${ }^{51}$. However, aldosterone-mediated renal sodium reabsorption was not reproducibly seen in animal with intact adrenal glands 52,53 . If animals were adrenalectomized prior to treatment with physiological doses of aldosterone, the expected antinatriuretic effect was clearly present. These observations lead to the idea that aldosterone must be physiologically regulated by substances most likely generated by or derived from the adrenal gland.

Uete and Venning ${ }^{54}$, described candidate adrenal steroids, which were able to interfere with the renal antinatriuretic actions of mineralocorticoid. Administration of cortisol or its 11dehydro (11-keto) metabolite, cortisone, attenuated the antinatriuretic response to both 
DOCA and aldosterone in the adenalectomized rat model. This blunting effect of cortisol and cortisone was dose dependent. Later, Alberti and Sharp ${ }^{55}$ suggested a mechanism by demonstrating that cortisone functioned as an aldosterone antagonist. Cortisone had no direct effect on sodium transport by itself but it was able to limit aldosterone nuclear binding even though cortisone does not bind well to either MRs or GRs.

Toad urinary bladders are a model of the mammalian collecting duct, which contain MRs and $11 \beta$-HSD-2 with no reductase activity. In our laboratory, toad bladders exposed to the 11-dehydro (11-keto) product of corticosterone, 11-dehydrocorticosterone, and then stimulated with aldosterone exhibited a markedly suppressed response in trans-epithelial sodium transport compared to controls stimulated with aldosterone alone ${ }^{56}$. A similar pattern was seen when bladders were exposed to corticosterone and then stimulated with aldosterone. Both corticosterone and 11-dehydrocorticosterone also suppressed aldosterone induced renal sodium retention in the adrenalectomized rat model ${ }^{57}$. In separate studies, we were able to show that 11-dehydrocorticosterone alone does not directly activate mineralocorticoid receptors but it is able to blunt aldosterone activation of these same receptors $^{58}$. Interestingly, 11-dehydrocorticosterone has no effect on dexamethasone binding to glucocorticoid receptors. Odermatt and his colleagues extended these receptor binding studies in demonstrating that both 11-dehydrocorticosterone and cortisone in concentrations as low as $50 \mathrm{nM}$ block aldosterone $10 \mathrm{nM}$ induced MR activation in transfected HEK-293 cells $^{59}$. Taken together then, ample evidence exists that the 11-dehydro metabolites of the endogenous glucocorticoids, cortisol and corcorticosterone, blunt aldosterone stimulated electrolyte transport not by directly binding to MR but by somehow preventing aldosterone from translocating to its nuclear binding site. Our laboratory now has extended this idea and we have demonstrated that 11-dehydrocorticosterone also blunts the pro-fibrotic actions of aldosterone in a dose dependent fashion ${ }^{36}$.

Are 11-dehydro metabolites of endogenous glucocorticoids locally generated by the kidney in concentrations that would be biologically significant? The endogenously produced glucocorticoids cortisol and corticosterone are metabolized in the kidney by isoforms of the enzyme $11 \beta$-Hydroxysteroid Dehydrogenase (11 $\beta$-HSD). Mammalian renal proximal tubules contain $11 \beta$-HSD-1, which uses NADP as a cofactor and has a $\mathrm{Km}$ in the range of $1 \mu \mathrm{M}$ for glucocorticoids ${ }^{60-63}$. While in most other sites in the body this isoform of the enzyme is bidirectional, in the kidney it appears to function only as a dehydrogenase generating 11dehydro products ${ }^{60,61}$. Renal collecting duct epithelial cells containing MRs also have $11 \beta$ HSD-2, an isoform that is dependent on NAD as a co-factor and has a $\mathrm{Km}$ in the $10 \mathrm{nM}$ range ${ }^{64}$. Could these two enzymes locally produce enough 11-dehydro metabolite to adequately attenuate the effects of aldosterone? In an attempt to answer this question, a few calculations need to be combined with what is already known. The average plasma concentration of cortisol in the human is $10 \mu \mathrm{gram} / \mathrm{dl}$ (the actual range is 5 to $20 \mu \mathrm{gram} / \mathrm{dl}$ ) and approximately $10 \%$ of that cortisol normally exists in a non-protein bound free state. Assume the average glomerular filtration rate for a human is $100 \mathrm{ml} / \mathrm{minute}(1 \mathrm{dl} / \mathrm{min})$ then the kidney filters about $1,440 \mu$ grams of free cortisol in a 24 -hour period. We know that only about $50 \mu$ grams of cortisol can be directly recovered in a 24 hour urine collection (about $3.5 \%$ of the filtered cortisol) and that the major metabolites are 11-dehydro glucocorticoids 
and their Ring A reduced derivatives ${ }^{65}$. Thus it is quite likely that adequate concentrations of cortisone and/or 11-dehydrocorticosterone are produced.

The 11-dehydro metabolites of cortisol and corticosterone are effective endogenously produced inhibitors of aldosterone action in tissues containing classical MRs. How they perform this task remains to be fully elucidated. Yet one still can ask the question; do they also work on atypical or non-classical membrane bound MRs? To date, the binding studies necessary to answer this question haven't been done. In preliminary experiments conducted in the murine model, it does appear that 11-dehydrocorticosterone can limit aldosterone induced increase in mesangial cell number and accompanying matrix ${ }^{36}$. This is significant since is appears likely that mesangial cells contain non-classical MRs as previously discussed.

Lastly, is sodium somehow linked to aldosterone-induced fibrosis? The many papers have noted that previously injured renal tissue demonstrated an enhanced degree of fibrosis if the animals were maintained on a high salt diet and treated with mineralocorticoids ${ }^{66-69}$.

Reduction in dietary sodium intake seemed to be protective especially when combined with aldosterone antagonists. In addition to stimulating sodium transport in renal collecting duct epithelial cells via classical MRs, aldosterone acutely increases sodium hydrogen ion antiporter activity in cells with non-classical MRs ${ }^{42,70}$ so there is a link between aldsterone and sodium, either through transepithelial transport or cell signaling. To try and separate the effects on sodium from the effects on transport, we cultured renal collecting duct epithelial cells (IMCD) in plastic dishes. The cells grew with their basolateral surface adhering to the plastic dish so that no real transepithelial sodium transport could take place. Under these conditions, we observed that aldosterone was able to induce pro-fibrotic changes with increased extracellular matrix production. We also repeated this experiment but cultured the IMCD on semi-permeable supports so the cells could maintain polarity and transport sodium. The cells were stimulated with aldosterone $10 \mathrm{nM}$ for 48 hours but this time amiloride was added to the medium bathing the apical surface to block the aldosterone sensitive sodium channel $(\mathrm{ENaC})$. As before, extracellular matrix increased in the absence of active sodium transmembrane transport (figure 4). These preliminary findings lead us to the view that in IMCD, active aldosterone stimulated sodium transport is not needed in order to see the fibrotic changes. Whether sodium somehow enhances that fibrotic process though cell signaling can't be answered from present data.

\section{SUMMARY}

In re-examining our case vignette, it became clear that our patient's hyperaldosteronism was going to be a life long condition. The natural history of her chronic disease could be seen as our patient reached adolescence with the subtle fall in GFR and development of low-grade proteinuria. Treatment options included the use of multiple anti-hypertensive agents and attempts to directly block the actions of aldosterone with spironolactone. As with any chronic condition, the ultimate success or failure of treatment depends on the effectiveness of drugs and the willingness and ability of the patient to comply with the therapy. In our case, compliance became a real compounding issue. Although the patient was never biopsied, it seems likely that fibrotic changes developed within both kidneys. As fibrosis 
replaced normal renal tissue, it also is likely that the endogenous renal protective effects of $11 \beta$-HSD metabolites against aldosterone action became less as well.

At the present moment, we know that aldosterone clearly can be a pro-fibrotic agent and can exert this effect in fairly low concentrations approaching the high physiological range. What prevents the fibrotic change from occurring is the fact that a prolonged and/or repetitive exposure seems to be necessary. Recognizing that aldosterone has a pro-fibrotic as well as a physiologic role regulating salt and water balance, an endogenous system is in place to counter excessive and unnecessary aldosterone activity, the 11-dehydro (11-keto) metabolites of cortisol and corticosterone. Renal 11 $\beta$-HSD-2 present in collecting duct cells may then perform two functions; first to prevent inappropriate glucocorticoid activation of MRs and second, to locally generate 11-dehydro metabolites, which limit aldosterone activity (figure 5). These dual roles can be extended to $11 \beta-\mathrm{HSD}-1$ contained in renal proximal tubules; this isoform provides a source of 11-dehydro-metabolites that are released in a paracrine fashion into the urine or blood and gain access to the collecting duct epithelial cells downstream. With these concepts in mind, it seems reasonable to consider the use of aldosterone inhibitors like spironolactone and agents, which might enhance renal 11 $\beta$-HSD activity (if and when they become available) in patients either at risk of or with active chronic kidney disease.

\section{References}

1. Greene EL, Kren S, Hostetter TH. Role of aldosterone in the remnant kidney model in the rat. J Clin Invest. 1996; 98:1063-1068. [PubMed: 8770880]

2. Selye H. Anticortisol action of aldosterone. Science. 1955; 121:368-369. [PubMed: 13237995]

3. Klinge U, Theuer S, Krott E, Fiebeler A. Absence of circulating aldosterone attenuates foreign body reaction around surgical sutures. Langenbecks Arch Surg. 2009; 395:429-435. [PubMed: 19277698]

4. Slight SH, Chilakamarri VK, Nasr S, Dhalla AK, Ramires FJ, Sun Y, Ganjam VK, Weber KT. Inhibition of tissue repair by spironolactone: role of mineralocorticoids in fibrous tissue formation. Mol Cell Biochem. 1998; 189:47-54. [PubMed: 9879653]

5. Huang S, Zhang A, Ding G, Chen R. Aldosterone-induced mesangial cell proliferation is mediated by EGF receptor transactivation. Am J Physiol Renal Physiol. 2009; 296:F1323-F1333. Epub 2009 Apr 1321. [PubMed: 19339632]

6. Squarize CH, Castilho RM, Bugge TH, Gutkind JS. Accelerated wound healing by mTOR activation in genetically defined mouse models. PLoS. 5:e10643.

7. Lieberthal W, Levine JS. The role of the mammalian target of rapamycin (mTOR) in renal disease. J Am Soc Nephrol. 2009; 20:2493-2502. Epub 2009 Oct 2429. [PubMed: 19875810]

8. Lu M, Wang J, Jones KT, Ives HE, Feldman ME, Yao LJ, Shokat KM, Ashrafi K, Pearce D. mTOR complex-2 activates ENaC by phosphorylating SGK1. J Am Soc Nephrol. 2010; 21:811-818. [PubMed: 20338997]

9. Naray-Fejes-Toth A, Helms MN, Stokes JB, Fejes-Toth G. Regulation of sodium transport in mammalian collecting duct cells by aldosterone-induced kinase, SGK1: structure/function studies. Mol Cell Endocrinol. 2004; 217:197-202. [PubMed: 15134818]

10. Schwartz GJ, Haycock GB, Edelmann CM Jr, Spitzer A. A simple estimate of glomerular filtration rate in children derived from body length and plasma creatinine. Pediatrics. 1976; 58:259-263. [PubMed: 951142]

11. Brem AS, Oyer CE, Noto RB. Progressive hypertension associated with hypokalemic alkalosis. J Pediatr. 1991; 118:479-484. [PubMed: 1999795] 
12. Rocha R, Stier CT Jr, Kifor I, Ochoa-Maya MR, Rennke HG, Williams GH, Adler GK. Aldosterone: a mediator of myocardial necrosis and renal arteriopathy. Endocrinology. 2000; 141:3871-3878. [PubMed: 11014244]

13. Weber KT, Sun Y, Guarda E. Structural remodeling in hypertensive heart disease and the role of hormones. Hypertension. 1994; 23:869-877. [PubMed: 8206620]

14. Young MJ, Funder JW. Mineralocorticoids, salt, hypertension: effects on the heart. Steroids. 1996; 61:233-235. [PubMed: 8733007]

15. Brown NJ. Aldosterone and end-organ damage. Curr Opin Nephrol Hypertens. 2005; 14:235-241. [PubMed: 15821416]

16. Funder J. Mineralocorticoids and cardiac fibrosis: the decade in review. Clin Exp Pharmacol Physiol. 2001; 28:1002-1006. [PubMed: 11903303]

17. Hollenberg NK. Aldosterone in the development and progression of renal injury. Kidney Int. 2004; 66:1-9. [PubMed: 15200407]

18. Remuzzi G, Cattaneo D, Perico N. The aggravating mechanisms of aldosterone on kidney fibrosis. J Am Soc Nephrol. 2008; 19:1459-1462. Epub 2008 Jun 1411. [PubMed: 18550649]

19. Briet M, Schiffrin EL. Aldosterone: effects on the kidney and cardiovascular system. Nat. 6:261273. Epub 2010 Mar 2016.

20. Eddy AA. Progression in chronic kidney disease. Adv Chronic Kidney Dis. 2005; 12:353-365. [PubMed: 16198274]

21. Iwano M, Neilson EG. Mechanisms of tubulointerstitial fibrosis. Curr Opin Nephrol Hypertens. 2004; 13:279-284. [PubMed: 15073485]

22. Eddy AA, Fogo AB. Plasminogen Activator Inhibitor-1 in Chronic Kidney Disease: Evidence and Mechanisms of Action. J Am Soc Nephrol. 2006; 17:2999-3012. Epub 2006 Oct 2911. [PubMed: 17035608]

23. Liu Y. Renal fibrosis: new insights into the pathogenesis and therapeutics. Kidney Int. 2006; 69:213-217. [PubMed: 16408108]

24. Blasi ER, Rocha R, Rudolph AE, Blomme EA, Polly ML, McMahon EG. Aldosterone/salt induces renal inflammation and fibrosis in hypertensive rats. Kidney Int. 2003; 63:1791-1800. [PubMed: 12675855]

25. Sato A, Saruta T, Funder JW. Combination therapy with aldosterone blockade and reninangiotensin inhibitors confers organ protection. Hypertens Res. 2006; 29:211-216. [PubMed: 16778327]

26. Hostetter TH, Rosenberg ME, Ibrahim HN, Juknevicius I. Aldosterone in progressive renal disease. Semin Nephrol. 2001; 21:573-579. [PubMed: 11709805]

27. Han KH, Kang YS, Han SY, Jee YH, Lee MH, Han JY, Kim HK, Kim YS, Cha DR. Spironolactone ameliorates renal injury and connective tissue growth factor expression in type II diabetic rats. Kidney Int. 2006; 70:111-120. Epub 2006 May 2024. [PubMed: 16723984]

28. Aldigier JC, Kanjanbuch T, Ma LJ, Brown NJ, Fogo AB. Regression of existing glomerulosclerosis by inhibition of aldosterone. J Am Soc Nephrol. 2005; 16:3306-3314. Epub 2005 Sep 3328. [PubMed: 16192423]

29. Ikeda H, Tsuruya K, Toyonaga J, Masutani K, Hayashida H, Hirakata H, Iida M. Spironolactone suppresses inflammation and prevents L-NAME-induced renal injury in rats. Kidney Int. 2009; 75:147-155. Epub 2008 Oct 2015. [PubMed: 18923385]

30. Christ M, Wehling M. Rapid actions of aldosterone: lymphocytes, vascular smooth muscle and endothelial cells. Steroids. 1999; 64:35-41. [PubMed: 10323671]

31. Miyata K, Rahman M, Shokoji T, Nagai Y, Zhang GX, Sun GP, Kimura S, Yukimura T, Kiyomoto $\mathrm{H}$, Kohno M, Abe Y, Nishiyama A. Aldosterone stimulates reactive oxygen species production through activation of NADPH oxidase in rat mesangial cells. J Am Soc Nephrol. 2005; 16:29062912. Epub 2005 Aug 2931. [PubMed: 16135774]

32. Terada Y, Kuwana H, Kobayashi T, Okado T, Suzuki N, Yoshimoto T, Hirata Y, Sasaki S. Aldosterone-stimulated SGK1 activity mediates profibrotic signaling in the mesangium. J Am Soc Nephrol. 2008; 19:298-309. Epub 2008 Jan 2009. [PubMed: 18184857] 
33. Leroy V, De Seigneux S, Agassiz V, Hasler U, Rafestin-Oblin ME, Vinciguerra M, Martin PY, Feraille E. Aldosterone activates NF-kappaB in the collecting duct. J Am Soc Nephrol. 2009; 20:131-144. Epub 2008 Nov 2005. [PubMed: 18987305]

34. Zhang A, Jia Z, Guo X, Yang T. Aldosterone induces epithelial-mesenchymal transition via ROS of mitochondrial origin. Am J Physiol Renal Physiol. 2007; 293:F723-F731. Epub 2007 Jun 2027. [PubMed: 17596522]

35. Klanke B, Cordasic N, Hartner A, Schmieder RE, Veelken R, Hilgers KF. Blood pressure versus direct mineralocorticoid effects on kidney inflammation and fibrosis in DOCA-salt hypertension. Nephrol Dial Transplant. 2008; 23:3456-3463. Epub 2008 May 3430. [PubMed: 18515791]

36. Brem AS, Morris DJ, Ge Y, Dworkin LD, Tolbert E, Gong R. Direct Fibrogenic Effects of Aldosterone on Normotensive Kidney: An Effect Modified by 11 \{beta\}-HSD Activity. Am J Physiol Renal Physiol. 2010; 298:F1178-F1187. [PubMed: 20200098]

37. Reungjui S, Hu H, Mu W, Roncal CA, Croker BP, Patel JM, Nakagawa T, Srinivas T, Byer K, Simoni J, Wesson D, Sitprija V, Johnson RJ. Thiazide-induced subtle renal injury not observed in states of equivalent hypokalemia. Kidney Int. 2007; 72:1483-1492. Epub 2007 Oct 1410. [PubMed: 17928827]

38. Porter GA, Bogoroch R, Edelman IS. On the Mechanism of Action of Aldosterone On Sodium Transport: the Role of Rna Synthesis. Proc Natl Acad Sci U S A. 1964; 52:1326-1333. [PubMed: 14243504]

39. Marver D, Stewart J, Funder JW, Feldman D, Edelman IS. Renal aldosterone receptors: studies with $(3 \mathrm{H})$ aldosterone and the anti-mineralocorticoid $(3 \mathrm{H})$ spirolactone (SC-26304). Proc Natl Acad Sci U S A. 1974; 71:1431-1435. [PubMed: 4364539]

40. Rossier BC, Wilce PA, Edelman IS. Spironolactone antagonism of aldosterone action on Na+ transport and RNA metabolism in toad bladder epithelium. J Membr Biol. 1977; 32:177-194. [PubMed: 192893]

41. Farman N, Kusch M, Edelman IS. Aldosterone receptor occupancy and sodium transport in the urinary bladder of Bufo marinus. Am J Physiol. 1978; 235:C90-C96. [PubMed: 211853]

42. Wehling M, Bauer MM, Ulsenheimer A, Schneider M, Neylon CB, Christ M. Nongenomic effects of aldosterone on intracellular $\mathrm{pH}$ in vascular smooth muscle cells. Biochem Biophys Res Commun. 1996; 223:181-186. [PubMed: 8660367]

43. Shibata S, Nagase M, Yoshida S, Kawachi H, Fujita T. Podocyte as the target for aldosterone: roles of oxidative stress and Sgk1. Hypertension. 2007; 49:355-364. Epub 2007 Jan 2002. [PubMed: 17200434]

44. Naray-Fejes-Toth A, Fejes-Toth G. The sgk, an aldosterone-induced gene in mineralocorticoid target cells, regulates the epithelial sodium channel. Kidney Int. 2000; 57:1290-1294. [PubMed: 10760056]

45. Husted RF, Sigmund RD, Stokes JB. Mechanisms of inactivation of the action of aldosterone on collecting duct by TGF-beta. Am J Physiol Renal Physiol. 2000; 278:F425-F433. [PubMed: 10710547]

46. Kellner M, Peiter A, Hafner M, Feuring M, Christ M, Wehling M, Falkenstein E, Losel R. Early aldosterone up-regulated genes: new pathways for renal disease? Kidney Int. 2003; 64:1199-1207. [PubMed: 12969137]

47. Mishina T, Scholer DW, Edelman IS. Glucocorticoid receptors in rat kidney cortical tubules enriched in proximal and distal segments. Am J Physiol. 1981; 240:F38-F45. [PubMed: 7457603]

48. Okada H, Kikuta T, Inoue T, Kanno Y, Ban S, Sugaya T, Takigawa M, Suzuki H. Dexamethasone induces connective tissue growth factor expression in renal tubular epithelial cells in a mouse strain-specific manner. Am J Pathol. 2006; 168:737-747. [PubMed: 16507889]

49. Brem AS. The Janus effect: two faces of aldosterone. Kidney Int. 2009; 75:137-139. [PubMed: 19116642]

50. Porter GA, Edelman IS. The Action of Aldosterone and Related Corticosteroids On Sodium Transport Across the Toad Bladder. J Clin Invest. 1964; 43:611-620. [PubMed: 14149914]

51. Stanton BA. Role of adrenal hormones in regulating distal nephron structure and ion transport. Fed Proc. 1985; 44:2717-2722. [PubMed: 2410298] 
52. Barger AC, Berlin RD, Tulenko JF. Infusion of aldosterone, 9-alpha-fluorohydrocortisone, and antidiuretic hormone into the renal artery of normal and adrenalectomized unanesthetized dogs: effect on electrolyte and water excretion. Endocrinology. 1958; 62:804-815. [PubMed: 13548099]

53. Morris DJ, Berek JS, Davis RP. The physiological response to aldosterone in adrenalectomized and intact rats and its sex dependence. Endocrinology. 1973; 92:989-993. [PubMed: 4686328]

54. Uete T, Venning EH. The effect of cortisone, hydrocortisone, and 9-alpha-fluoro-16-alphahydroxy-delta-hydrocortisone on the action of desoxycorticosterone and aldosterone with respect to electrolyte excretion. Endocrinology. 1960; 67:62-69. [PubMed: 13840184]

55. Alberti KGMM, Sharp GWG. Identification of four types of steroid by their interaction with mineralocorticoid receptors in the toad bladder. J Endocrinology. 1970; 48:563-574. [PubMed: 5489019]

56. Brem AS, Matheson KL, Barnes JL, Morris DJ. 11-Dehydrocorticosterone, a glucocorticoid metabolite, inhibits aldosterone action in toad bladder. American Journal of Physiology. 1991; 261:F873-F879. [PubMed: 1951719]

57. Souness GW, Myles K, Morris DJ. Other physiological considerations of protective mechanisms of mineralocorticoid action. Steroids. 1994; 59:142-147. [PubMed: 8191544]

58. Morris DJ, Souness GW, Brem AS, Oblin ME. Interactions of mineralocorticoids and glucocorticoids in epithelial target tissues. Kidney Int. 2000; 57:1370-1373. [PubMed: 10760069]

59. Odermatt A, Arnold P, Frey FJ. The intracellular localization of the mineralocorticoid receptor is regulated by 11 beta-hydroxysteroid dehydrogenase type 2. J Biol Chem. 2001; 276:28484-28492. Epub 22001 May 28411. [PubMed: 11350956]

60. Gong R, Morris DJ, Brem AS. Human renal 11beta-hydroxysteroid dehydrogenase 1 functions and co-localizes with COX-2. Life Sci. 2008; 82:631-637. Epub 2008 Jan 2002. [PubMed: 18261751]

61. Brem AS, Bina RB, King T, Chobanian MC, Morris DJ. Influence of dietary sodium on the renal isoforms of 11 beta- hydroxysteroid dehydrogenase [In Process Citation]. Proc Soc Exp Biol Med. 1997; 214:340-345. [PubMed: 9111524]

62. Brem AS, Bina RB, Fitzpatrick C, King T, Tang SS, Ingelfinger JR. Glucocorticoid metabolism in proximal tubules modulates angiotensin II-induced electrolyte transport. Proc Soc Exp Biol Med. 1999; 221:111-117. [PubMed: 10352121]

63. Brem AS, Bina B, Matheson KL, Barnes JL, Morris DJ. Developmental changes in rat renal 11 beta-hydroxysteroid dehydrogenase. Kidney International. 1994; 45:679-683. [PubMed: 8196270]

64. Naray-Fejes-Toth A, Fejes-Toth G. 11 beta-Hydroxysteroid dehydrogenase in renal collecting duct cells. [Review]. Steroids. 1994; 59:105-110. [PubMed: 8191537]

65. Best R, Walker BR. Additional value of measurement of urinary cortisone and unconjugated cortisol metabolites in assessing the activity of 11 beta-hydroxysteroid dehydrogenase in vivo. Clin Endocrinol (Oxf). 1997; 47:231-236. [PubMed: 9302399]

66. Vallon V, Wyatt AW, Klingel K, Huang DY, Hussain A, Berchtold S, Friedrich B, Grahammer F, Belaiba RS, Gorlach A, Wulff P, Daut J, Dalton ND, Ross J Jr, Flogel U, Schrader J, Osswald H, Kandolf R, Kuhl D, Lang F. SGK1-dependent cardiac CTGF formation and fibrosis following DOCA treatment. J Mol Med. 2006; 84:396-404. Epub 2006 Apr 2008. [PubMed: 16604333]

67. Artunc F, Amann K, Nasir O, Friedrich B, Sandulache D, Jahovic N, Risler T, Vallon V, Wulff P, Kuhl D, Lang F. Blunted DOCA/high salt induced albuminuria and renal tubulointerstitial damage in gene-targeted mice lacking SGK1. J Mol Med. 2006; 84:737-746. Epub 2006 Aug 2010. [PubMed: 16924469]

68. Lam EY, Funder JW, Nikolic-Paterson DJ, Fuller PJ, Young MJ. Mineralocorticoid receptor blockade but not steroid withdrawal reverses renal fibrosis in deoxycorticosterone/salt rats. Endocrinology. 2006; 147:3623-3629. Epub 2006 Apr 3620. [PubMed: 16627578]

69. Lea WB, Kwak ES, Luther JM, Fowler SM, Wang Z, Ma J, Fogo AB, Brown NJ. Aldosterone antagonism or synthase inhibition reduces end-organ damage induced by treatment with angiotensin and high salt. Kidney Int. 2009; 75:936-944. Epub 2009 Feb 2018. [PubMed: 19225557]

70. Young M, Funder J. Mineralocorticoid action and sodium-hydrogen exchange: studies in experimental cardiac fibrosis. Endocrinology. 2003; 144:3848-3851. [PubMed: 12933657] 
RAAS activation Hyperkalemia Obesity Low salt intake

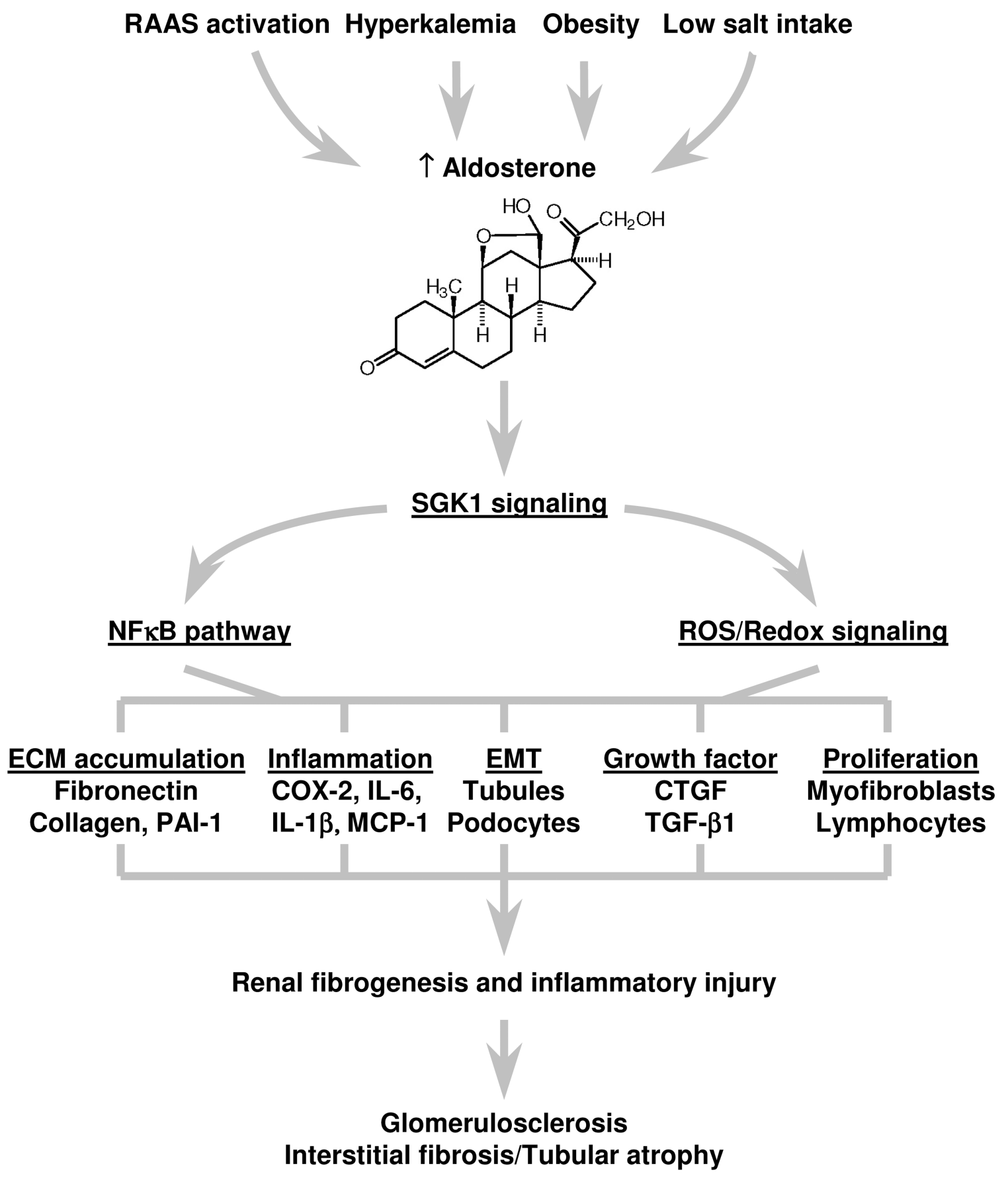

Figure 1.

Chronically stimulate Aldosterone secretion can lead to activation of pro-inflammatory and pro-fibrotic pathways in mineralocorticoid responsive cells. In the kidney, activation of these pathways is associated with both glomerular sclerosis and interstitial fibrosis with tubular atrophy. 

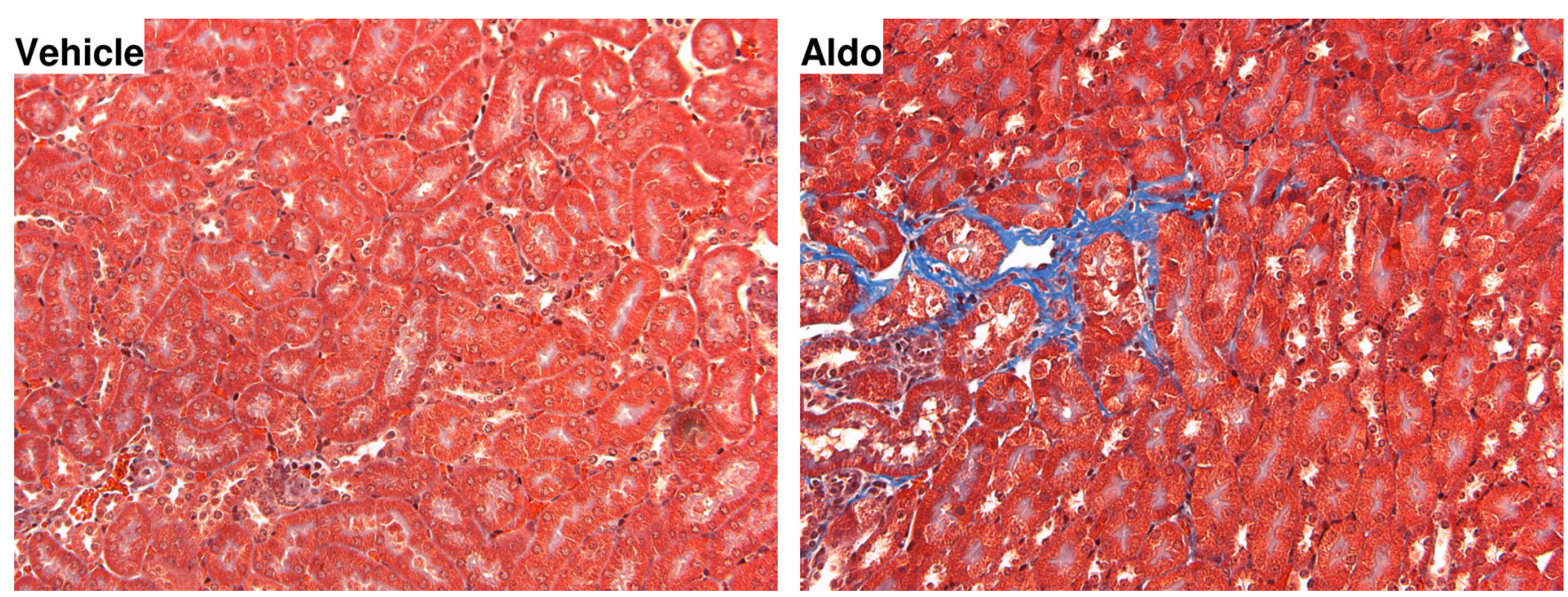

Figure 2.

Compared to controls (left panel), Aldosterone ( 8 micrograms $/ \mathrm{kg} / \mathrm{day}$ ) (right panel) is capable of inducing early fibrotic interstitial changes in both cortex and medulla after only one week in an adrenalectomized mice without pre-existing hypertension or renal injury. The blue staining represents collagen matrix (magnification $\times 400$ ). See reference 34 for details. 


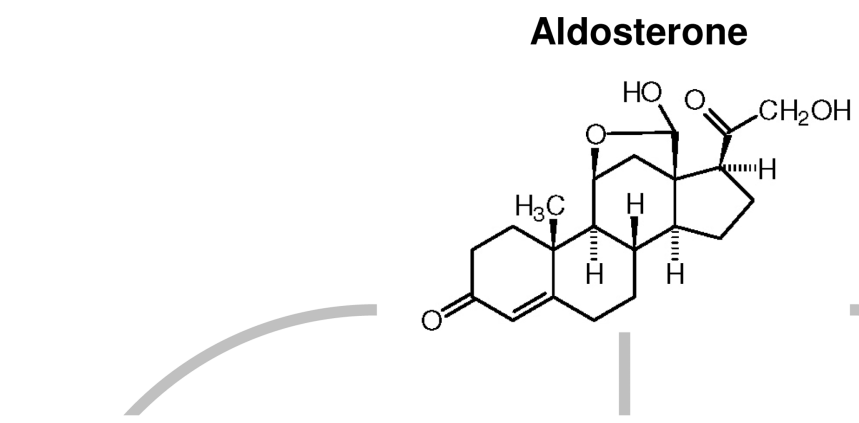

Nanomolar

100 nanomolar

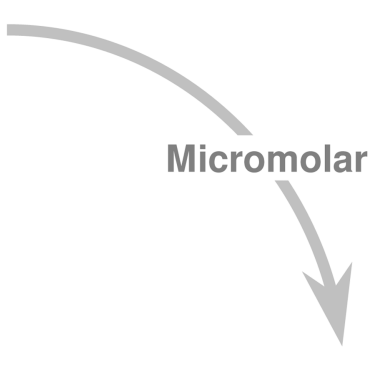

Classic MR

Principal and intercalated cells of collecting duct

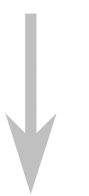

Protein kinase SGK1 activation

$\uparrow \mathrm{ENaC}$

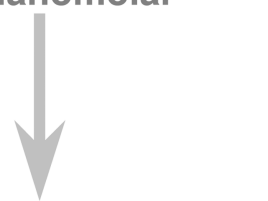

Non-Classic MR

Mesangial cells VSM cells Proximal tubular cells?

Non-genomic/Rapid

$\uparrow \Delta \mathrm{Ca}_{i} ; \mathrm{Na}: \mathrm{H}$ exchange $\underline{\text { GR }}$

Most mammalian cells

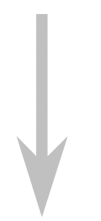

Protein kinase SGK1 activation

$\uparrow$ Na transport ?

Figure 3.

Aldosterone can bind to several different receptors including classical MR, non-classical or atypical membrane associated MR, and GR depending on the cell type and function. 


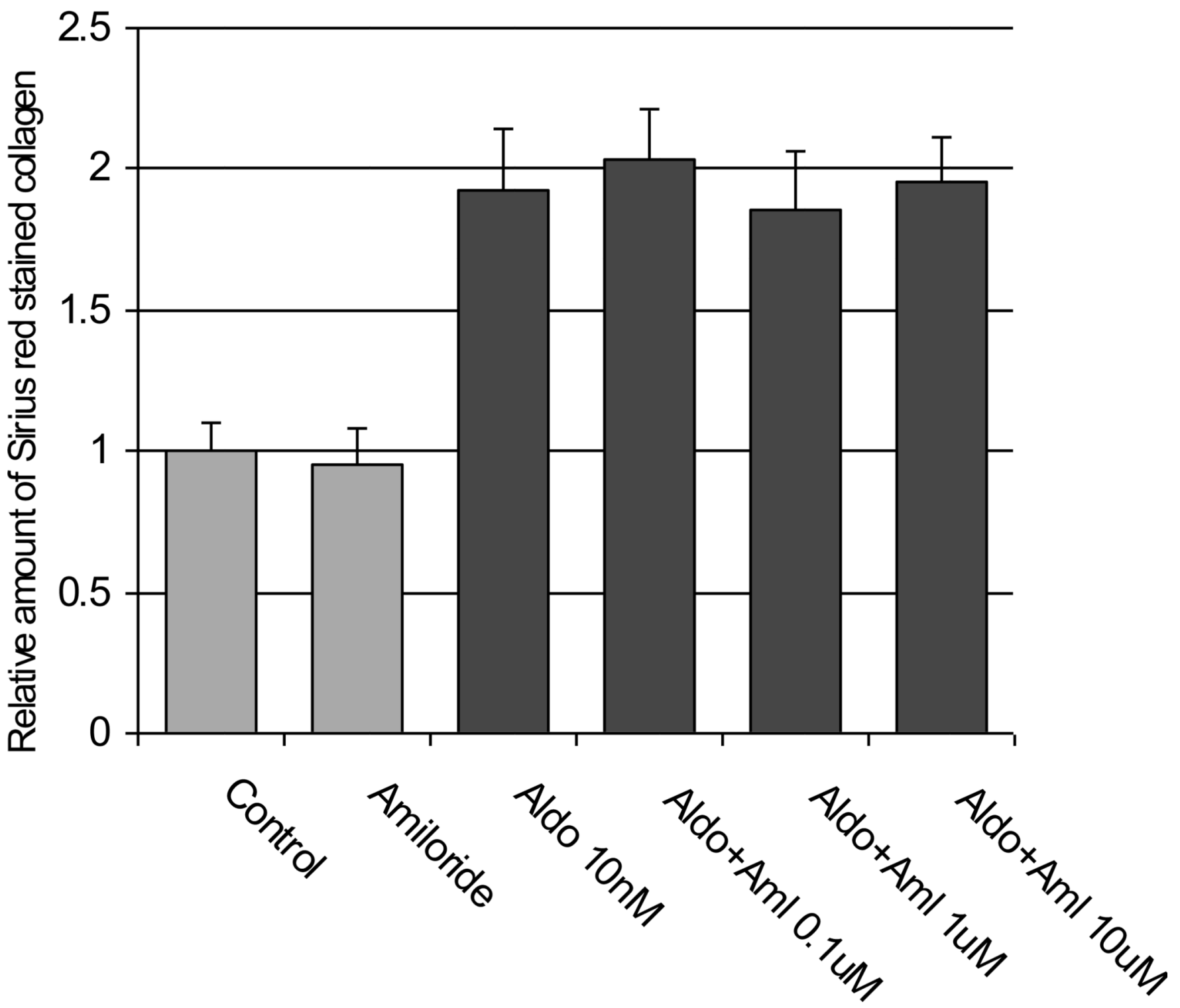

Figure 4.

IMCD generated extracellular matrix measured by Sirius Red staining when the cells were exposed to Aldosterone $10 \mathrm{nM}$ for 48 hours. The cells were grown on semi-permeable supports and were polarized to allow for transmembrane sodium transport. When amiloride was added to the medium bathing the apical cell surface inhibiting the sodium channel $(\mathrm{ENaC})$, the Aldosterone induced increase in matrix occurred even with sodium transport blocked. 


\section{Two Roles for Renal $11 \beta-H S D$}

\section{Cortisol/ Corticosterone

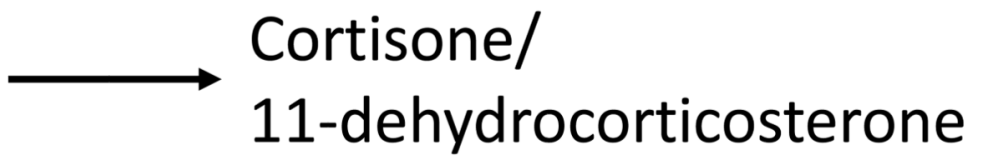

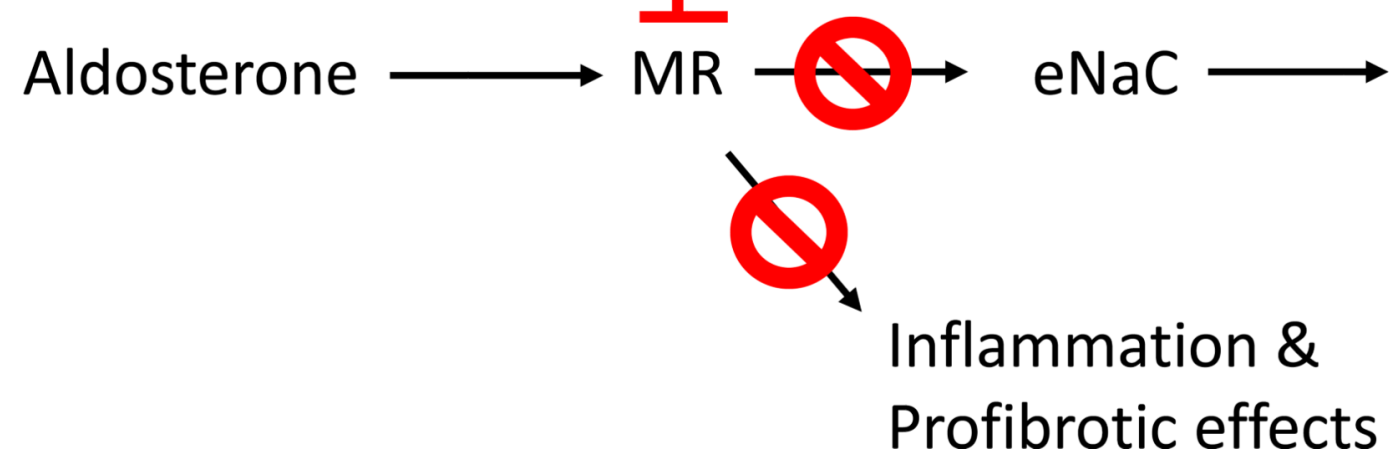

Figure 5.

Renal 11 $\beta$-Hydroxysteroid Dehydrogenase isoforms perform two functions; first to prevent endogenous glucocorticoids from inappropriately binding to MR and second to generate 11dehydro (11-keto) glucocorticoid metabolites, which serve to attenuate the actions of aldosterone in the kidney. 